\section{Relative Humidity and Nutrient Concentration Affect Nutrient Uptake and Growth of Begonia $\times$ hiemalis}

\author{
Hans R. Gislerød and Leiv M. Mortensen \\ Department of Horticulture, Agricultural University of Norway, 1432 \\ Aas-NLH, Norway
}

\begin{abstract}
Additional index words. transpiration, salinity
\end{abstract}
Abstract. Young plants of Begonia $\times$ hiemalis Fotsch 'Schwabenland Red' were grown for 10 weeks at $60 \% \pm 5 \%$ or $90 \% \pm 5 \%$ relative humidity $(\mathrm{RH})$ in growth rooms. Plants were watered with three nutrient solution concentrations $\left(1,2\right.$, and $\left.4 \mathbf{m S} \cdot \mathrm{cm}^{-1}\right)$. Transpiration of the plants was $56 \%$ lower at the high RH level, while the concentration of the nutrient solution had less effect $(10 \%$ to $20 \%)$. Plant dry weight, height, width, and leaf size were significantly higher at the higher RH. Dry weight, height, width, and leaf size of the plants were higher in the $2 \mathrm{mS} \cdot \mathrm{cm}^{-1}$ than in the $1 \mathrm{mS} \cdot \mathrm{cm}^{-1}$ solution when grown at high RH, but not at a lower RH. A further increase of the nutrient solution concentration either had no effect or was detrimental. The higher RH decreased the concentration of $N, P$, and $K$ in leaves and stems of plants, but an increase in the concentration of the nutrient solution increased the concentration of $N, P, K$, and $\mathrm{Ca}$ in both leaves and stems. At termination of the experiment, the number of flowers and flower buds and percent of flowering plants was higher at $90 \% \mathrm{RH}$ than at $60 \%$ RH. These values also were higher at the higher nutrient solution concentrations. Time of anthesis was not affected.

During the last few years, a change from single glass to double acrylic or polycarbonate coverings has taken place in the greenhouse industry. These materials have enabled growers to reduce energy consumption up to $50 \%$. However, a high air humidity is often experienced in such greenhouses because of the higher inner surface temperature and less water condensation on the surface (Sebesta and Reiersen, 1981). No large differences in plant growth have been observed, even though light levels have been reduced by $15 \%$ (Reiersen and Sebesta, 1981). Increased relative humidity (RH) $(50 \%$ to $85 \%)$ increased the growth of lettuce (Tibbitts and Bottenberg, 1976), and Ageratum, Petunia, and Tagetes responded positively to increasing RH from $40 \%$ to $65 \%$ (Hoffmann and Rawlins, 1971). Agricultural plants, including wheat, sugarbeet, and kale, also responded positively to increased RH (60\% to $90 \%)$ (Ford and Theme, 1974). O'Leary and Knecht (1971) and Gislerød et al. (1987) reported that an increase in RH decreased transpiration in plants. This result indicates that the proportion between uptake of water and nutrient elements is altered as the RH changes. The current experiment was conducted to gain more information about the effects of increased RH on plant growth and nutrient uptake.

Young plants of Begonia $\times$ hiemalis 'Schwabenland Red' were planted in limed sphagnum peatmoss with $0.2 \mathrm{~kg}$ of Fritt No.

Received for publication 8 June 1987. Report no. 364. The cost of publishing this paper was defrayed in part by the payment of page charges. Under postal regulations, this paper therefore must be hereby marked advertisement solely to indicate this fact.
$36 / \mathrm{m}^{3}$ in $12-\mathrm{cm}$ plastic pots (0.6 liter) and placed on plates so no water would leak out. The initial weight was $0.5 \mathrm{~g} / \mathrm{plant}$. The experiment was a two RH level by three nutrient solution concentration factorial and plants were grown in four walk-in growth rooms. Two were kept at a $\mathrm{RH}$ of $60 \% \pm$ $5 \%$ and the other two at $90 \% \pm 5 \%$, corresponding to $8.5 \pm 1$ and $2.1 \pm 1 \mathrm{mbar}$ water vapor deficit, respectively. Relative humidity was measured by means of a psychrometer (Hydrophil 4455, Ultrakust, Gerätebau, Gmbh. \& Co., Ruhmannsfelden).
Air temperature was $18.5 \pm 0.5 \mathrm{C}$. Soil temperature was 1.0 to $2.0 \mathrm{C}$ and 0.0 to $1.0 \mathrm{C}$ lower than air temperature at $60 \%$ and $90 \%$ $\mathrm{RH}$, respectively, because of moisture evaporation from the soil surface. Leaf temperature, measured by means of an IR thermometer (PRT-10L, Barnes Engineering, Stamford, Corm.), was 0.0 to $0.5 \mathrm{C}$ lower than the air temperature at $60 \% \mathrm{RH}$; air and leaf temperature were the same at $90 \% \mathrm{RH}$.

The photon flux density, measured with a Lambda LI-185B instrument with quantum sensor $(400-700 \mathrm{~nm})$ at the top of the plants, was $110 \pm 10 \mu \mathrm{mol} \cdot \mathrm{s}^{-1} \cdot \mathrm{m}^{-}{ }^{2}$. The light source was fluorescent tubes (Philips TL 65/ $33 \mathrm{RS}$ ) and the photoperiod was $18 \mathrm{hr} \cdot \mathrm{day}^{-1}$. Plants were exposed for 2 weeks to a 10$\mathrm{hr} \cdot \mathrm{day}^{-1}$ photoperiod, beginning 1 week after the start of the experiment, to-induce flowering. The experiment lasted 10 weeks.

Plants were watered as needed with $50 \mathrm{ml}$ of a complete nutrient solution using three concentrations. The salinities of the solutions were: 1 (half), 2 (normal), and 4 (double) $\mathrm{mS} \cdot \mathrm{cm}^{-1}$. The solutions were made of $\mathrm{Ca}\left(\mathrm{NO}_{3}\right), \mathrm{KNO}_{3}, \mathrm{MnSO}_{4}$, and MPM Superba (Mg, P + micro). The normal solution contained the nutrient elements in the following concentrations (mg.liter $\left.{ }^{-1}\right)$ : N, 176; $\mathrm{P}, 36 ; \mathrm{K}, 232$; Ca, 114; Mg, 39; S, 35; Fe, 2.0; Mn, 0.9; Zn, 0.18; Cu, 0.12; B, 0.18; Mo> 0.03 .

The pots were always supplied with sufficient water but never were water-logged. The plants never suffered from water stress.

Plants and soil were analyzed 40 days after the start of the experiment and at harvest. Data presented in Tables 1 and 2 were taken at harvest. The soil was analyzed for $\mathrm{pH}$, salinity ( $\mathrm{SSE}$ ), $\mathrm{NH}_{4}-\mathrm{N}, \mathrm{NO}_{3}-\mathrm{N}, \mathrm{P}, \mathrm{K}, \mathrm{Ca}$, $\mathrm{Mg}$, and $\mathrm{S}$. Leaves and stems were analyzed separately for Kjeldahl-N, P, K, Ca, Mg, and $\mathrm{S}$. The analytical procedure was as de-

Table 1. Effect of RH and nutrient concentration on the content of Kjeldahl-N, P, K, Ca, and Mg (percent of dry matter) in the leaves and stem of Begonia 'Schwabenland Red'.

\begin{tabular}{|c|c|c|c|c|c|c|c|}
\hline \multirow[b]{3}{*}{ Nutrient } & \multirow[b]{3}{*}{$\mathrm{RH}(\%)$} & \multicolumn{6}{|c|}{ Nutrient concn $\left(\mathrm{mS} \cdot \mathrm{cm}^{-1}\right)$} \\
\hline & & \multicolumn{3}{|c|}{ Leaves } & \multicolumn{3}{|c|}{ Stem } \\
\hline & & 1 & 2 & 4 & 1 & 2 & 4 \\
\hline \multirow[t]{2}{*}{$\mathrm{N}$} & 60 & 3.9 & 4.1 & 4.3 & 3.3 & 3.2 & 3.5 \\
\hline & 90 & 2.3 & 3.4 & 3.9 & 1.7 & 2.5 & 3.1 \\
\hline \multirow[t]{2}{*}{$P$} & 60 & 0.55 & 0.62 & 0.67 & 0.63 & 0.68 & 0.6 \\
\hline & 90 & 0.32 & 0.47 & 0.59 & 0.47 & 0.47 & 0.6 \\
\hline \multirow[t]{2}{*}{ K } & 60 & 2.6 & 2.4 & 2.9 & 4.9 & 5.1 & 5.1 \\
\hline & 90 & 1.3 & 2.2 & 2.2 & 3.4 & 4.5 & 4.7 \\
\hline \multirow[t]{2}{*}{$\mathrm{Ca}$} & 60 & 1.26 & 1.53 & 1.67 & 0.52 & 0.70 & 0.7 \\
\hline & 90 & 1.10 & 1.32 & 1.62 & 0.66 & 0.68 & 0.6 \\
\hline \multirow[t]{2}{*}{$\mathrm{Mg}$} & 60 & 0.71 & 0.64 & 0.60 & 0.35 & 0.31 & 0.2 \\
\hline & 90 & 0.47 & 0.60 & 0.54 & 0.30 & 0.30 & 0.2 \\
\hline \multicolumn{2}{|c|}{ Significant effects } & & $\mathrm{N}$ & $\mathrm{P}$ & $\mathrm{K}$ & $\mathrm{Ca}$ & $\mathrm{M}_{1}$ \\
\hline \multicolumn{8}{|c|}{ Leaves } \\
\hline \multicolumn{2}{|c|}{$\mathrm{RH}$} & & $* * *$ & $* * *$ & $* * *$ & NS & * \\
\hline \multirow{2}{*}{\multicolumn{2}{|c|}{$\begin{array}{l}\text { Concn } \\
\mathrm{RH} \times \text { conen }\end{array}$}} & & $* * *$ & $* * *$ & $* * *$ & $* * *$ & NS \\
\hline & & & $* * *$ & $* *$ & $* * *$ & NS & ** \\
\hline \multicolumn{2}{|c|}{ LSD 0.05} & & 0.34 & 0.049 & 0.202 & 0.262 & $0.0^{-}$ \\
\hline \multicolumn{8}{|c|}{ Stem } \\
\hline \multicolumn{2}{|c|}{$\begin{array}{l}\text { RH } \\
\text { Concn }\end{array}$} & & $* * *$ & $* * *$ & ** & $*$ & NS \\
\hline \multicolumn{2}{|c|}{ Concn } & & $* *$ & $* *$ & $*$ & $* * *$ & ** \\
\hline \multicolumn{2}{|c|}{$\mathrm{RH} \times$ concn } & & $*$ & NS & NS & $* *$ & NS \\
\hline \multicolumn{2}{|c|}{ LSD 0.05} & & 0.65 & 0.064 & 0.56 & 0.057 & 0.11 \\
\hline
\end{tabular}


scribed by Selmer-Olsen and Gislerød (1981), where the plant tissues were dried and milled to homogeneous samples. Dry-matter was determined after drying at $105 \mathrm{C}$. Ash was determined after heating the samples for 2 $\mathrm{hr}$ at 550C. The ash was treated with HCL and the elements were determined by flame photometry $(\mathrm{K})$, spectrophotometry $(\mathrm{P})$, and atomic absorption $(\mathrm{Ca}, \mathrm{Mg})$. Kjeldahl-N was determined with the phenate method after a digestion in $\mathrm{H}_{2} \mathrm{SO}_{4}$.

The peat was ashed at 550C and dissolved in $\mathrm{HCl}$. The total amount of $\mathrm{K}, \mathrm{P}, \mathrm{Ca}$, and $\mathrm{Mg}$ were determined as in the plant material. Total S was determined turbidimetrically as $\mathrm{BaSO}_{4}$ after treating the sample with $\mathrm{Mg}\left(\mathrm{NO}_{3}\right)_{2}$, ashing, and dissolving in $\mathrm{HCl}$. $\mathrm{NH}_{4}-\mathrm{N}$ and $\mathrm{NO}_{3}-\mathrm{N}$ were determined in a 2$\mathrm{M} \mathrm{KCl}$ extract as indophenol blue and by Griess reagent, respectively. The $\mathrm{pH}$ was measured in an extract of 1 peat $: 2.5$ water $(\mathrm{v} / \mathrm{v})$. Salinity was measured in the water vacuumed from the peat that was first watersaturated.

At the termination of the experiment, the following characteristics were also recorded: fresh and dry weights of the plants, plant height and width, leaf size (length $\times$ width of the two largest leaves/2), curling of the leaves (with a scale of 0 to 3 , where $0=$ no curling and $3=$ severe curling), number of flowers amd flower buds, and percent of plants with flowers.

The experimental design was a split-plot with $\mathrm{RH}$ as the main plot and salinity as the sub-plot. Each treatment was replicated two times with 10 plants per replicate. All data were subjected to an analysis of variance. Duncan's multiple range test was used to determine significant differences between treatment means at $P=0.05$ for the plants and LSD for nutrient analyses.,

Plant growth. Plant water consumption was $383 \mathrm{ml} \cdot \mathrm{g}^{-1}$ of dry weight at low RH and 214 $\mathrm{ml} \cdot \mathrm{g}^{-1}$ of dry weight at high $\mathrm{RH}$ for the 10 weeks. Water consumption was $10 \%$ to $20 \%$ lower in the nutrient solution at $4 \mathrm{mS} \cdot \mathrm{cm}^{-1}$ than in the one at $1 \mathrm{mS} \cdot \mathrm{cm}^{-1}$

The plants grown at high RH and normal or strong nutrient solution had a significantly higher dry weight than plants grown at low $\mathrm{RH}$ (Fig. 1). Increasing nutrient concentration had "no effect on the dry weight of the plants when grown at low RH. At the higher $\mathrm{RH}$, the dry weight of the plants was significantly higher at the higher nutrient concentrations. There was a significantly higher percentage of dry matter for plants grown at low compared to high RH (Fig. 1). There was also a significant interaction between $\mathrm{RH}$ and nutrient concentration. The highest percentage of dry matter was in plants grown at low RH and high nutrient concentration.

Plants were significantly taller and wider and had a greater leaf size $(P=0.001)$ when grown at high RH and high nutrient concentration (Figs. 2 and 3). At the highest RH, leaf size, plant diameter, and plant height were largest with medium or high nutrient concentration. At low RH, there was little or no effect from increasing the nutrient concentration (Fig. 2). There was also a signif-

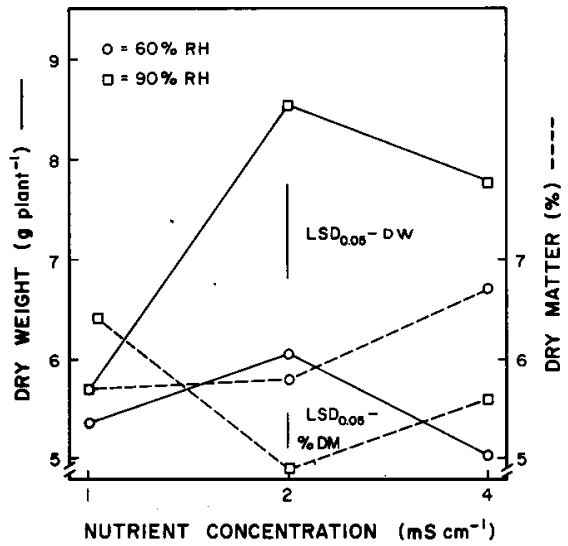

Fig. 1. Effect of RH and concentration of the nutrient solution on dry weight (-) (interaction significant, $\mathrm{P}=0.001)$ and percentage of dry matter (-- -) (interaction significant, $\mathrm{P}=$ 0.01) of Begonia' 'Schwabenlan Red'.

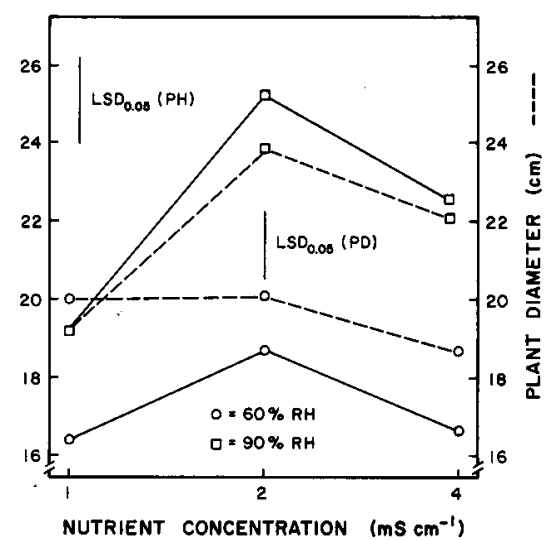

Fig. 2. Effect of RH and concentration of the nutrient solution on plant height $(-)$ (interaction significant, $P=0.05)$ and diameter (- - ) (interaction significant, $\boldsymbol{P}=$ 0.001) of Begonia 'Schwabenland Red'.

icant interaction between RH and nutrient concentration on plant width, plant height, and leaf size.

There was less curling of the leaves at high $\mathrm{RH}$ than at low $\mathrm{RH}(\mathrm{P}=0.001)$. The curling of the leaves was also less with high than with low nutrient concentration $(\mathrm{P}=$ 0.05 ). There was no interaction between $\mathrm{RH}$ and nutrient concentration on the curling of the leaves (data not shown).

The number of flowers and flower buds were significantly higher with increasing nutrient concentration, as well as for plants grown at high compared to low RH. There was no significant interaction between $\mathrm{RH}$ and nutrient concentration on number of buds and flowers (Fig. 4). The number of plants that were flowering at the time of harvest was higher (15\%) for plants grown at high than at low RH.

Nutrient content in the plants. The content of Kjeldahl-N, P, and $\mathrm{K}$ in leaves and stems was higher at low than at high RH (Table 1). The $\mathrm{Mg}$ and $\mathrm{S}$ content of the leaves were also highest with low RH, but the Ca content of the leaves and $\mathrm{Mg}$ content of the stems were not affected by RH.

Increasing nutrient concentration in-

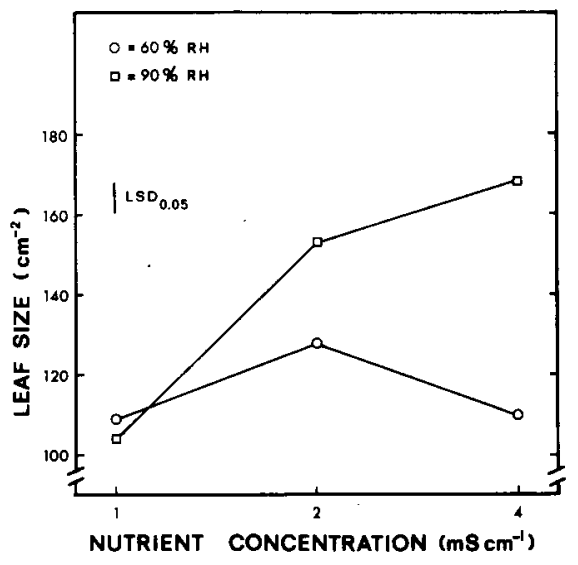

Fig. 3. Effect of RH and nutrient concentration on leaf size (length $\mathrm{x}$ width) as a mean of the two largest leaves (measured in square centimeters) (interaction significant).

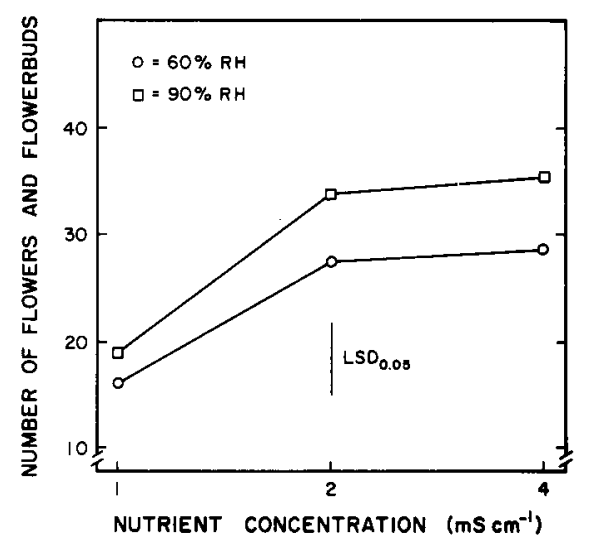

Fig. 4. Effect of RH and the concentration of the nutrient solution on the number of flowers and buds of Begonia 'Schwabcnland Red' at termination of the experiment (interaction not significant).

creased the content of Kjeldahl-N, P, K, and $\mathrm{Ca}$ in both leaves and stems. There was no effect on the Mg content in the leaves and a significant decrease in stems (Table 1).

There was an interaction between RH and nutrient concentration on Kjeldahl-N in leaves and stems and $\mathrm{P}$ and $\mathrm{K}$ in leaves, but not in the stems (Table 1). There were no interactions for $\mathrm{Ca}, \mathrm{Mg}$, and $\mathrm{S}$ content of leaves and stems. There was no difference in $\mathrm{N}$ content of the two sampling dates for either leaves or stems; for P, it was lower in the stems at the end of the experiment, but not for the leaves. The $\mathrm{K}$ content of the leaves was especially higher at high $\mathrm{RH}$ at the end of the experiment, while there was no difference in the stems.

Soil. The content of $\mathrm{NO}_{3}-\mathrm{N}, \mathrm{K}$, and $\mathrm{P}$ in the soil was higher for plants grown at low than at high RH, as well as significantly higher with increasing concentration of the nutrient solution (Table 2). For $\mathrm{NO}_{3}-\mathrm{N}, \mathrm{K}$, and $\mathrm{P}$ in the soil, there was an interaction between $\mathrm{RH}$ and nutrient concentration. For $\mathrm{Mg}$, there was an increase in the content in the soil with increasing concentration of the nutrient solution, but no effect of RH. The content of $\mathrm{Ca}$ in the soil was not significantly affected 
Table 2. Effect of RH and nutrient concentration given to Begonia 'Schwabenland Red' on the concentration of $\mathrm{NO}_{3}-\mathrm{N}, \mathrm{K}$, and $\mathrm{P}$ in the growing medium $(\mathrm{g} / \mathrm{kg}$ dry matter).

\begin{tabular}{|c|c|c|c|c|}
\hline \multirow[b]{2}{*}{ Nutrient } & \multirow[b]{2}{*}{$\mathrm{RH}(\%)$} & \multicolumn{3}{|c|}{$\begin{array}{l}\text { Nutrient concn } \\
\left(\mathrm{mS} \cdot \mathrm{cm}^{-1}\right)\end{array}$} \\
\hline & & 1 & 2 & 4 \\
\hline $\mathrm{NO}_{3}-\mathrm{N}$ & $\begin{array}{l}60 \\
90\end{array}$ & $\begin{array}{l}0.31 \\
0.08\end{array}$ & $\begin{array}{l}1.87 \\
0.25\end{array}$ & $\begin{array}{l}6.01 \\
2.14\end{array}$ \\
\hline \multirow[t]{2}{*}{ K } & 60 & 2.05 & 4.78 & 8.43 \\
\hline & 90 & 1.10 & 1.83 & 4.60 \\
\hline \multirow[t]{2}{*}{$P$} & 60 & 0.50 & 0.83 & 1.47 \\
\hline & .90 & 0.47 & 0.61 & 0.98 \\
\hline \multicolumn{2}{|c|}{ Significant effect } & $\underline{\mathrm{NO}_{3}-\mathrm{N}}$ & $\mathbf{K}$ & $\mathrm{P}$ \\
\hline \multirow{2}{*}{\multicolumn{2}{|c|}{$\begin{array}{l}\mathrm{RH} \\
\text { Concn }\end{array}$}} & $*_{* * *}$ & $\overline{* * *}$ & \\
\hline & & $* * *$ & $* * *$ & $* * *$ \\
\hline \multicolumn{2}{|c|}{$\mathrm{RH} \times$ concn } & *** & *** & **** \\
\hline \multicolumn{2}{|c|}{ LSD 0.05} & 1.18 & 1.51 & 0.23 \\
\hline
\end{tabular}

by either RH or the concentration of the nutrient solution.

The dry weight, height, and width of the plants and relative leaf size were greater with high than with low $\mathrm{RH}$ at normal and high concentrations of the nutrient solution. With low nutrient concentrations, there was little or no difference in growth of the plants at the two RH levels. Raper and Smith (1975) reported an increase in the dry weight of tobacco with high RH (90\%), compared to low $\mathrm{RH}(65 \%)$, when the plants received high $\mathrm{N}$ application. No difference occurred at low $\mathrm{N}$. The $\mathrm{N}$ content for whole tobacco plants was greater when plants were grown at low rather than at high $\mathrm{RH}$ with high $\mathrm{N}$ application, while there was no difference at low $\mathrm{N}$ application. Our results agree with theirs to the extent that there was a higher content of $\mathrm{N}$ in the plants with low RH than with high RH; however, this was also the situation when low nutrient concentration was applied. The reason could be that, in our experiment, plants were given a constant concentration of the nutrient element with each watering. Plants grown at low RH used almost twice as much water as plants at high $\mathrm{RH}$ and, therefore, would have received more nutrient elements. The analysis of the growing medium also showed that the concentration of $\mathrm{NO}_{3}-\mathrm{N}$ and $\mathrm{K}$ was significantly lower at high than at low RH. Gislerød et al. (1987) reported that for many greenhouse plants given the same amount of fertilizer and grown at different RH (55\% to $60 \%$ vs. $90 \%$ to $95 \%$ ), the content of $\mathrm{N}$ in the leaves was generally lower for plants grown at high than at low $\mathrm{RH}$. They also reported that the contents of $\mathrm{P}, \mathrm{K}, \mathrm{Ca}$, and $\mathrm{Mg}$ in the leaves were lower for plants grown at high compared to low $\mathrm{RH}$. These differences were significant for Lycopersicon (K, $\mathrm{Ca}, \mathrm{Mg})$, Chrysanthemum $(\mathrm{K}, \mathrm{Ca})$, and Begonia $(\mathrm{P})$. In the present experiment, there were significantly higher contents of $\mathrm{N}, \mathrm{P}$, and $\mathrm{K}$ in both leaves and stems at low RH, which partly could be due to a higher content of these nutrient elements in the growing medium at low than at high $\mathrm{RH}$. For $\mathrm{Ca}$ and $\mathrm{Mg}$, there were no differences in the medium at the two RH levels, even though there was a higher content of $\mathrm{Mg}$ in the leaves and $\mathrm{Ca}$ in the stems at low RH. Collier and Tibbitts (1984) found a decrease in the $\mathrm{Ca}$ content of the outer leaves of lettuce with increasing RH (5\% vs. $74 \%$ ). The present results indicate that the uptake and transport of $\mathrm{Ca}$ to the leaves of Begonia is less sensitive to high RH than that of lettuce. There was an increase of $\mathrm{Mg}$ in the medium with increasing concentration of the nutrient solution, but the content of $\mathrm{Mg}$ in the stems was reduced instead of being increased. This agrees with the results for $\mathrm{Mg}$ uptake in tomato (Sonneveld, 1986).

Increased yield due to higher RH (45\% vs. $90 \%$ ) in a nonsaline root medium was observed for beets, radish, and wheat, while it had no effect on onion and corn and a negative effect on barley (Hoffman and Jobes, 1978; Hoffman and Rawlins, 1971). Salt tolerance increased for barley and corn at high $\mathrm{RH}$, but did not affect the tolerance of wheat (Hoffman and Jobes, 1978). In the present results, the growth of Begonia on a low saline medium was not influenced by $\mathrm{RH}$, but, on a higher saline medium, growth increased at-high but not at low RH. This result indicates that the tolerance and use of nutrient elements by Begonia is higher at high than at low RH.

Increased leaf size with increasing $\mathrm{RH}$ has previously been reported on lettuce, wheat, sugar beet, cotton, and several greenhouse plants (Ford and Thorne, 1974; Hoffman et al., 1971; Mortensen, 1986; Tibbitts and Bottenberg, 1976). Also, increased shoot and petiole elongation at high $\mathrm{RH}$ has increased plant weight (Mitchell and Hoff, 1977). Shortterm measurements of net $\mathrm{CO}_{2}$ uptake with Chrysanthemum have shown no effect at increasing RH from $50 \%$ to close to $100 \%$ (Mortensen, 1983). Similar results were found in Schefflera arboricola (Lorenzo-Minguez et al., 1985).

The number of flowers and flower buds per plant increased with RH and nutrient concentration for Saintpaulia (Mortensen, 1986). The number of flowers and buds per plant and the number of flowering plants was higher with increasing $\mathrm{RH}$ and nutrient solution concentration in the present experiment, but there was no difference in days to first open flower.

The RH interacts with salinity in plant growth, on dry weight, percentage of dry matter, plant height and diameter, and leaf size, but not on flowering. Relative humidity also interacted with the $\mathrm{N}, \mathrm{P}$, and $\mathrm{K}$ content of the leaves. This result indicates that growing plants at high $\mathrm{RH}$ is not only possible, but will give greater growth if the conductivity of the nutrient solution is increased.

\section{Literature Cited}

Collier, G.F. and T.W. Tibbitts. 1984. Effects of relative humidity and root temperature on calcium concentration and tipburn development in lettuce. J. Amer. Soc. Hort. Sci. 109:128-131.

Ford, M.A. and G.N. Thorne. 1974. Effects of atmospheric humidity on plant growth. Ann. Bet. 38:441-452.

Gislerød, H.R., A.R. Selmer-Olsen, and L.M. Mortensen. 1987. The effect of air humidity on nutrient uptake of some greenhouse plants. Plant \& Soil 102:193-196.

Hoffman, G.J. and J.A. Jobes. 1978. Growth and water relations of cereal crops as influenced by salinity and relative humidity. Agron. J. 70:765769 .

Hoffman, G.J. and S.L. Rawlins. 1971. Growth and water potential of root crops as influenced by salinity and relative humidity. Agron. J. 63:877-880.

Hoffman, G. J., S.L. Rawlins, M.J. Garber, and E.M. Cullen. 1971. Water relations and growth of cotton as influenced by salinity and relative humidity. Agron. J. 63:822-826.

Lorenzo-Minguez, P., R. Centemans, R. Gabriels, I. Tempens, and O. Verdonck. 1985. Effect of short-term water stress on leaf gas exchange processes and plant water potential in schefflera. HortScience 20:932-934.

Mitchell, C.A. and J.E. Hoff. 1977. Influence of ambient humidity and root zone shielding on tomato seedling growth. J. Amer. Soc. Hort. Sci. 102:587-590.

Mortensen, L.M. 1983. Growth responses of some greenhouse plants to environment. IX. Effect of $\mathrm{CO}_{2}$ on photosynthesis of Chrysanthemum $\times$ morifolium Ramat at different light, temperature and $\mathrm{O}_{2}$ levels. Meld. Norg. Landbr. Hoegsk. 62(11):1-12.

Mortensen, L.M. 1986. Effect of relative humidity on growth and flowering of some greenhouse plants. Scientia Hort. 29:301-307.

O'Leary, J.W. and G.N. Knecht. 1971. The effect of relative humidity on growth, yield and water consumption of bean plants. J. Amer. Soc. Hort. Sci. 96:263-265.

Raper, C. D., Jr., and W.T. Smith. 1975. Factors affecting the development of flue-cured tobacco grown in artificial environments. I. Effects of humidity and nitrogen nutrition. Agron. J. 67:307-312

Reiersen, D. and Z. Sebesta. 1981. A comparison of the effect of single glass and double acrylic sheeting on plant growth and development. Acts Hort. 115:401-408.

Sebesta, Z. and D. Reiersen. 1981. A comparison of the effect of single glass and double acrylic sheeting with respect to heat loss and effects on plant environment. Acts Hort. 115:409-416.

Selmer-Olsen, A.R. and H.R. Gislerød. 1981. Effect of root temperature on nutrient uptake by the chrysanthemum. Acts Hort. 176:427-433.

Sonneveld, C. 1986. Magnesium deficiency in rockwool grown tomatoes as affected by climactical conditions and plants nutrition. X. Intl. Plant Nutr. Colloq., Beltsville, Md.

Tibbitts, T.W. and G. Bottenberg. 1976. Growth of lettuce under controlled humidity levels. J. Amer. Soc Hort. Sci. 101:70-73. 